\title{
Using a Map to Reconstruct the Szekler Atlantis
}

\author{
János Jeney ${ }^{\mathrm{a}, *}$ \\ ${ }^{a}$ Institute of Hungarian Research, jeney.janos@mki.gov.hu \\ * Corresponding author
}

Keywords: Bözödújfalu, systematization, flooding, Ceauşecu,

\begin{abstract}
:
n 1965 Nicolae Ceauşescu came to power in Romania. Many in the west saw him as a communist leader who went against the will of Moscow. It got very little attention that he was intending to go through with a plan of systematization, which should have reduced the built up area and increased the population density of settlements. The goal was to move everybody into apartment blocks designed by the central committee of the communist party, at the same time destroying villages with all their cultural heritage.
\end{abstract}

Systematization was to be carried out in three phases: Firstly the full survey of the villages (1985-1990), secondly the construction of agricultural/industrial centres, (1990-1995) and finally the destruction of all villages and the banning of the construction of private houses. While in most of the country only the first phase was carried out, some villages were indeed destroyed. The preparations were done in secret and people were given very short notice to move out. These moves were well prepared and the village to be evicted and destroyed was previously surveyed by the government. The whole village was mapped and all houses were photographed.

As a result of the international reactions and its legacy, the most well known of the destroyed villages became Bözödújfalu (Bezid Nou), a village mainly inhabited the the ethnic Hungarian minority of Romania. The Küsmöd, the river flowing though the village did indeed flood from time to time and cause a lot of damage. A dam was planned on the Küsmöd that, according to the original plan would have only flooded a few houses on the outskirts of the villages. This was later changed and a much larger wall was built, creating a dam that would flood the whole village. Since the Hungarian minority felt that destroying their villages would destroy their traditional communities, protests broke out in Hungary as well as in some Western countries, especially in ones with large number of Hungarian migrants. The protest in Hungary was closely monitored by the secret services but this was the first demonstration since the start of communism not to be dispersed by the government.

Bözödújfalu was known as the last surviving village with Szekler Sabbatarian inhabitants. These were people of nonJewish descent who followed the Jewish faith. The village also had Roman Catholic and Unitarian inhabitants, who all lived side-by-side in peace for centuries. In times when the Sabbatarians were persecuted, all villagers protected them, hence they survived. After its destruction this heritage was also destroyed.

Bözödújfalu became the symbol of the destruction caused by systematization. The catholic church stood out of the water until 2014, when it collapsed. The picture of the church tower sticking out of the water was well known in Hungarian communities around the world.

The map made of the village during the during the survey recorded the state of each house in great detail. The houses are categorised into excellent, good and fair condition. Houses that have been thorn down by their owners before the map was made are also shown. This was officially to be used to determine the compensation to be paid to the owner. These were so low, that it was not possible to buy another house from any of them, regardless of the state of ones property. All roads and rivers were recorded, so we know exactly what the village looked like before its destruction. The planned minimum and maximum water levels are shown. The planned minimum level is around the water level seen today. 


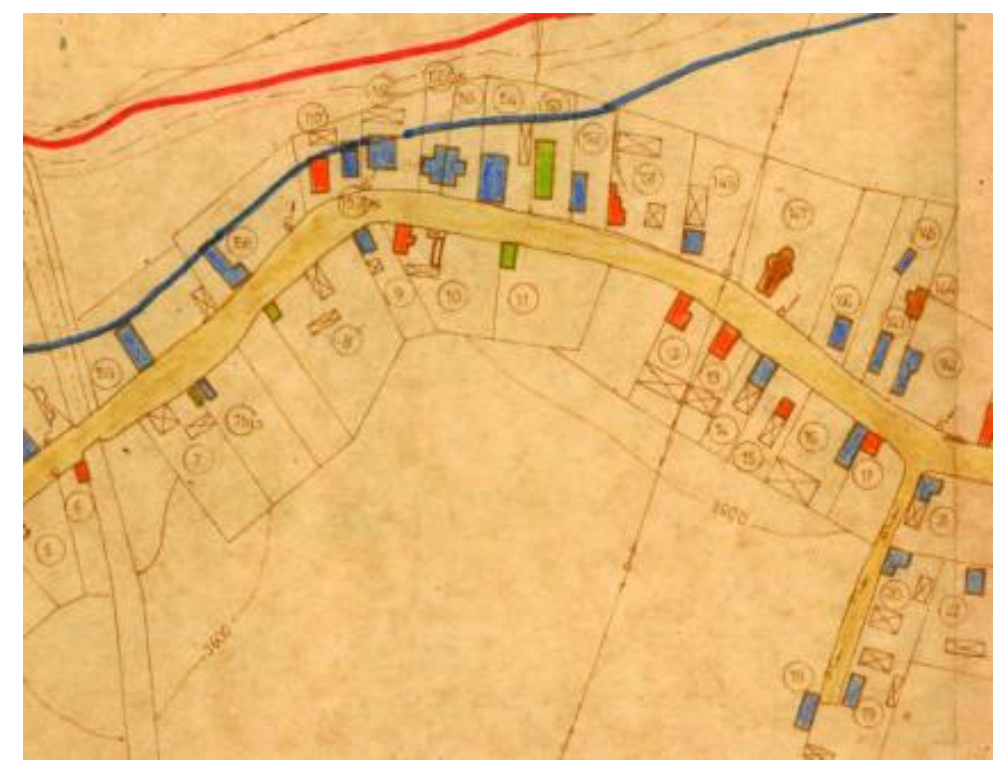

Figure 1. The map showing the houses in different colours. Red show houses in excellent condition, blue shows houses in good condition and green shows houses in fair condition. Brown show buildings that have been thorn down.

In the first year after the village was destroyed, few inhabitants of the village announced on local radio that they would meet near the village on the first Saturday of August. Following this on 3 August 1991 the first village meeting since the destruction took place. Since then the former villagers organised the village meeting on the first Saturday of August of each year. During the years the meeting place became a memorial site. At first only a memorial wall was constructed, and later memorial commemorating the soldiers who fell during the first world war was taken out of the water and placed on the site. A tower for a bell was constructed, and the church bell from the catholic church, which still stood at the time, was removed from the tower and taken to the village museum in Erdöszentgyörgy. Every year during the village meeting the bell is taken to the memorial site and is hung on the tower and rung. Families, former neighbours and friends meet and have a common commemoration at the site.

The map created during the survey of the village was used to create a three dimensional model made of wood that showed exactly what the village looked like at a scale of 1:400. The glass plain was placed above the model to show where the water levels are today. The houses are not painted in their original patterns, and were painted white instead. All other characteristics of the village are left the same. It can be clearly seen that the dam is much larger than the village and that the village was in the northeastern corner of the dam. In fact one street with few houses is was not flooded, but due to the lack of infrastructure the houses have been deserted, and their condition is constantly deteriorating making them uninhabitable. This can all be seen very clearly on this model. This model can be seen in the village museum in Erdőszentgyörgy.

The same map was used to construct an on site model of the village using grave markers that are called Kopjafa in Hungarian. These are wooden grave markers unique to Transylvania and are used by the Hungarian minority. Each house has one marker. The markers are arranged the way the village was constructed, with the name of the last owner of each house carved into the marker. This way anybody who visits the site can have a picture of what the village looked like. It can be said that the map created to prepare the destruction of the village is used today in order to commemorate its existence and preserve its heritage.

The village, despite being destroyed continues to live on. Its community holds its annual village meeting, the church that collapsed in 2014 is being rebuild to remind people that a village used to be here, and its inhabitants still regard it as their true home. The models created using the map of the villages preserve its picture for generations to come. 